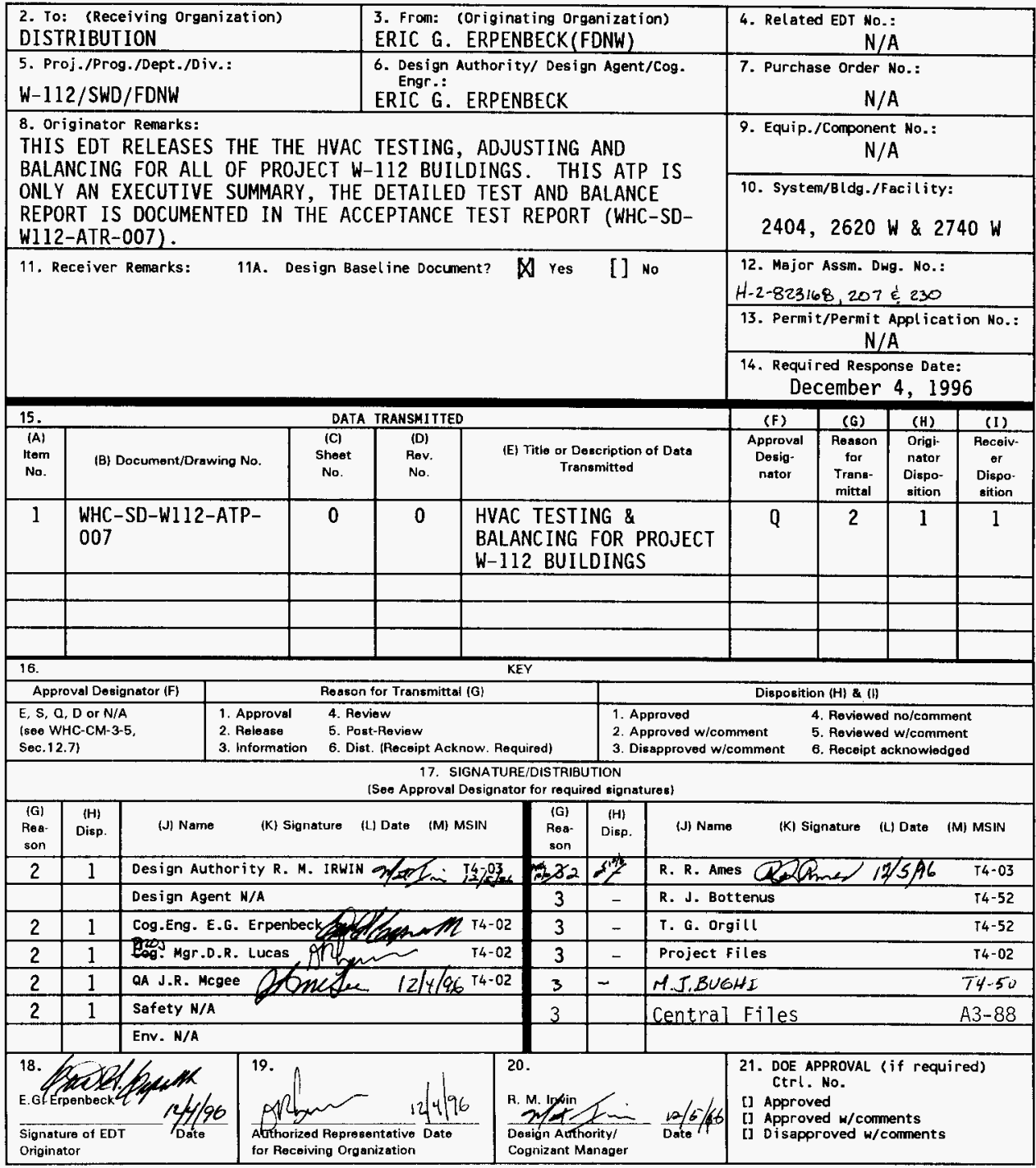




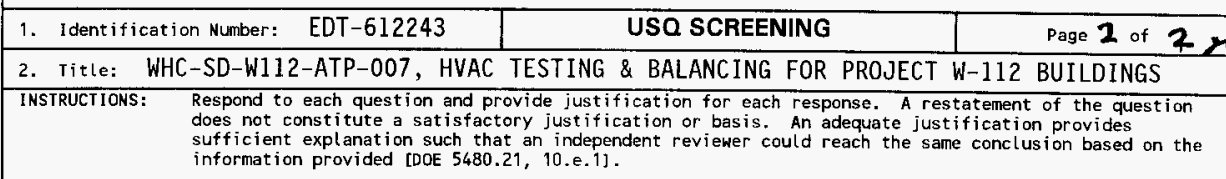

QUESTIONS

1. Does the proposed change or occurrence represent a change to the facility or procedures as described in the Authorization Basis?
[X] N/A
[] No
[] Yes/Maybe

BASIs: The $W-112$ project 2404 series buildings are not operational. The CWC ISB is not yet approved; the ventilation testing is part of the project completion and will be reviewed and approved as part of the readiness review checklist process, along with the approval of the ISB.

2. Does the proposed change or occurrence represent conditions that have not been analyzed in the Authorization Basis?
[X] N/A
[] No
[] Yes/Maybe

Basis: Same as 1 above.

3. Does the proposed change represent a test or experiment NOT described in the Authorization Basis that may affect the safe operation of the facility?

$[X]$ N/A [] No [] Yes/Maybe

BAsis: Same as 1 above.

4. Does the proposed change or occurrence represent a change to the Technical Safety Requirements or a reduction in the margin of safety defined in the Technical Safety Requi rements?

$[X] \mathrm{N} / \mathrm{A}$ [] No [] Yes/Maybe

BASIs: Same as 1 above.

usqe \#1 E. V. dosRamos

(Print Name)

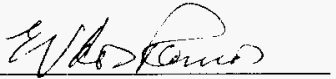

signature

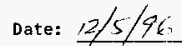

Datea
USQE \#2 R. R. Ames

(Print Name)

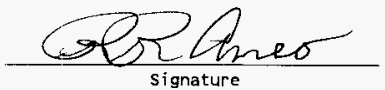

Date: $12 / 5 / 96$

If there is a YES/MAYBE response to questions 1, 2, 3, or 4, then a usa Evaluation must be completed.

The following guidance should be considered when completing this screening. This guidance should not be considered atlinclusive; additional factors may need to be considered depending on the nature of the proposed change.

Does the proposed change:

1) Modify, add, or delete a safety class function of a structure, system or component stated in the authorization basis?

2) Alter the design of a structure, system or component as described in the authorization basis?

3) Modify, add, or delete the description of operation, operating environment, or analyses of any system or component described in the authorization basis?

4) Modify, add, delete or conflict with any of the design bases stated in the authorization basis?

5) Conflict with the principle or general design criteria stated in the authorization basis?

6) Modify, add, or delete any plant design features described in the authorization basis?

7) Modify, add, or delete a flow diagram or facility drawing provided in the authorization basis?

8) Create the potential for new system or component interactions (e.g.. seismic, electrical breaker coordination)? 


\section{ACCEPTANCE TEST PROCEDURE FOR PROJECT W-112 HVAC TESTING, ADJUSTING AND BALANCING FOR 2404 SERIES, $2620 \mathrm{~W}$ AND $2740 \mathrm{~W}$}

Eric G. Erpenbeck

Fluor Daniel Northwest, Richland, WA 99352

U.S. Department of Energy Contract DE-AC06-96RL13200

$\begin{array}{lll}\text { EDT/ECN: } & 612243 & \text { UC: } 510 \\ \text { Org Code: } & 8 \text { KD } 30 & \text { Charge Code: } \\ \text { B\&R Code: } & 39 E W 31302 & \text { Total Pages: } 2\end{array}$

Key Words: HP $1 \& 2$, HP 1-4, Exhaust Fans, Roof Ventilators

Abstract: This document is an executive summary of the testing, adjusting and balancing completed for Project W-112 for the HVAC

systems. The actual results are document in the Acceptance Test Report.

TRADEMARK DISCLAIMER. Reference herein to any specific comercial product, process, or service by trade name, trademark, manufacturer, or otherwise, does not necessarily constitute or imply its endorsement, recommendation, or favoring by the United States Government or any agency thereof or its contractors or subcontractors.

Printed in the United States of America. To obtain copies of this document, contact: WHC/BCS Document Control Services, P.O. Box 1970, Mailstop H6-08, Richland HA 99352, Phone (509) 372-2420; Fax (509) 376-4989.
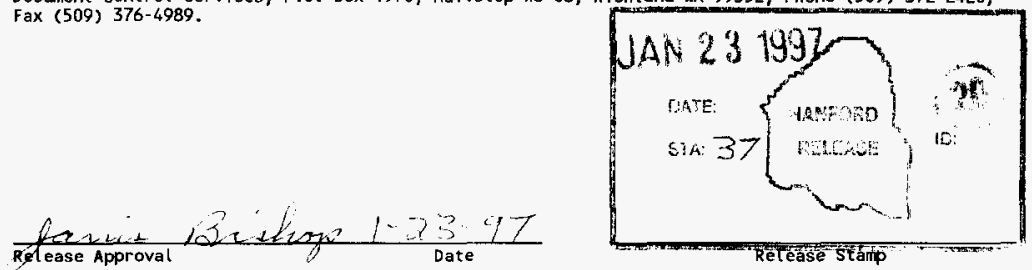

\section{Approved for Public Release}




\section{PROJECT W-112, HVAC TESTING, ADJUSTING, AND BALANCING REPORTS}

THREE LONG TERM DRUM STORAGE BUILDINGS 2404 WA, 2404 WB, 2404 WC. THE MAINTENANCE BUILDING $2620 \mathrm{~W}$, AND THE OFFICE FACILITY $2740 \mathrm{~W}$

\section{EXECUTIVE SUMMARY:}

Project W-112 was a design build contract which included three Long Term Drum Storage Buildings (2404 WA, $2404 \mathrm{WB}$ and $2404 \mathrm{WC}$ ), and office facility (2740 W) and a maintenance facility $(2620 \mathrm{~W})$. Because the project was a design build contract, the construction contractor retained configuration management of all Acceptance Test Procedures during construction. Hence an ATP was never released into the site configuration management system. However, the results of the testing, adjusting and balancing for all HVAC systems on W-112 will be available in the site configuration management system as an Acceptance Test Report (WHC-SD-W112-ATR-007). The ATR will document the acceptance of all field installed ventilation systems from the construction contractor by the owner. 